\title{
LOW-DENSITY URBANISM. WHAT IS IT?
}

\author{
n Interview with Bisserka Gaydarska and John Chapman \\ (Durham University, Department of Archaeology, Durham, \\ UK)
}

Tetiana Vodotyka - Ok, so my first question will be: how do archaeologists see urbanism and urban studies?

Bisserka Gaydarska - Well, the concept of urbanism was introduced in 1950 by the Australian archaeologist, Gordon Childe. He wrote the seminal paper in urban studies and it was called 'The Urban Revolution' in which he defined his famous ten criteria according to which given archaeological site or group could be classified as urban or not. And if a particular site had these ten criteria, one of which is writing, another one is craft specialization, this means that there was a surplus. There was enough surplus for some people not to do agricultural work, but to do services, which is one of the modern classification of a city - as a place offering services as oppose do villages that he makes agricultural production. So, that's what Childe introduced as early as 1950 to look for in the archaeological record.

But there are many other criteria which he was basically trying to translate. Very modern criteria at that time. He was trying to see how we can reconcile the record of classical cities, modern cities at that time, to what he could reach as far back as possible in time. And he came up with these ten criteria about urban sites. But one of the major characteristics of the urbanism he had introduced is that it needs to be a very densely packed occupation, people should have lived closely together, and they would have quarters and neighbourhoods. Everything that you would possibly associate with current living in current modern cities.

John Chapman - But it's a long time now since Childe has published his great paper in 1950 and lots more archaeological discoveries have been made. And the most important thing is that people have been finding cities not just in the Near East which Childe was talking about, but also in the New World, as well as in Africa and China. And quite often these cities are very different from the ones that Childe was talking about. So, in the New World for instance, in Maya cities, you might find five of Childe's criteria, but not the others. And in Africa the same. So, what this means is that slowly it has become increasingly difficult to define what the city really looks like. And that I think introduces a whole new world game into urban studies because you cannot make Childe's assumptions for the whole world. You have somehow to develop a general perspective which respects local urban perspectives too. You know that for me is the new challenge for urbanism.

Tetiana Vodotyka - And as far as I understood Gordon Childe's model didn't work and so another model has appeared.

John Chapman - Well, the thing is that Gordon Childe's model is the current model that dominates in archaeology. Still. Which makes 
other evidence very difficult to be appreciated. To see that maybe there are different kinds of cities. For example, we live in a very small place in Northern England. But just because it has a cathedral it is called a city, it is qualified as a city. At the same time, London is a city too. And how do you compare the two?

You can't possibly have one set of criteria that could be good enough to cover all the evidence from the past to the present for all the seven continents and make that concept work. This is very difficult. So, in the last probably ten years, less than ten years an alternative agenda has developed. Archaeologists are trying to question this model of Gordon Childe by saying: look, there is this kind of evidence which can't possibly be ignored just because we have this densely packed model of the Near East, and later the Romans, which dominates in archaeology. What we have to do is to introduce a bit more diversity in what we actually understand to qualify as urban and this is where we are. That's why we are in Ukraine because you know, if I told you ten years ago that probably the first cities in Europe came up in Ukraine that would be... nobody would ever look at you in a serious way. But I truly believe that the first cities in Europe and may be in the World have appeared in Ukraine. But we have to be absolutely clear about that. This is not what we find in a modern Iraq in the tell sites, it's a very different kind of urban site.

So basically, the sites that we are talking about, the concept that questions that is very simple - it's just low-density urbanism which is to say that there are the sites (and there are growing evidence and growing number of the sites across the World) that suggest that people were living together, but not next to each other. But in overall density which is rather low than what modern cities look like. But when we say modern cities, like Kyiv may be, but if think of maybe localities, that happened to the Eastern Coast of America in which all the cities sort of blended together over one huge area ('megalopolis'). If you measure the density of these areas you find out that it is not what Gordon Childe was suggesting, but it is much lower density and there fore to suggest that this kind of evidence is only acceptable for present times. It's wrong because we have evidence that this has been happening in the past as well.

John Chapman - There are very good examples of low-density cities in Ukraine. For instance, if you go to the Southern part where near the Tripillian sites where we are working if you go to Novoarkhangelsk or you go to Kirovograd (now it is called Kropyvnytskyi -ed.).

Tetiana Vodotyka - Industrial city, big industrial city. Yes.

John Chapman - Yes. In fact, there are huge green areas, the green residentials. I haven't measured this, but I think if you went out and look at Novoarhangelsk and Kropyvnytskyi they would turn out to be low-density urban centers and, so it just challenges the whole notion of what the city is. And so the other most important point of low-density living is the potential for expansion. Take Shanghai, for example. Twenty years ago, Shanghai covered about a thousand hectares and it was quite high-density in the middle, but the edges were low-density. And then in the last twenty years Shanghai expanded to cover two hundred square kilometers and it's massive. But if you go out of Shanghai, 
Bisserka Gaydarska on excavation

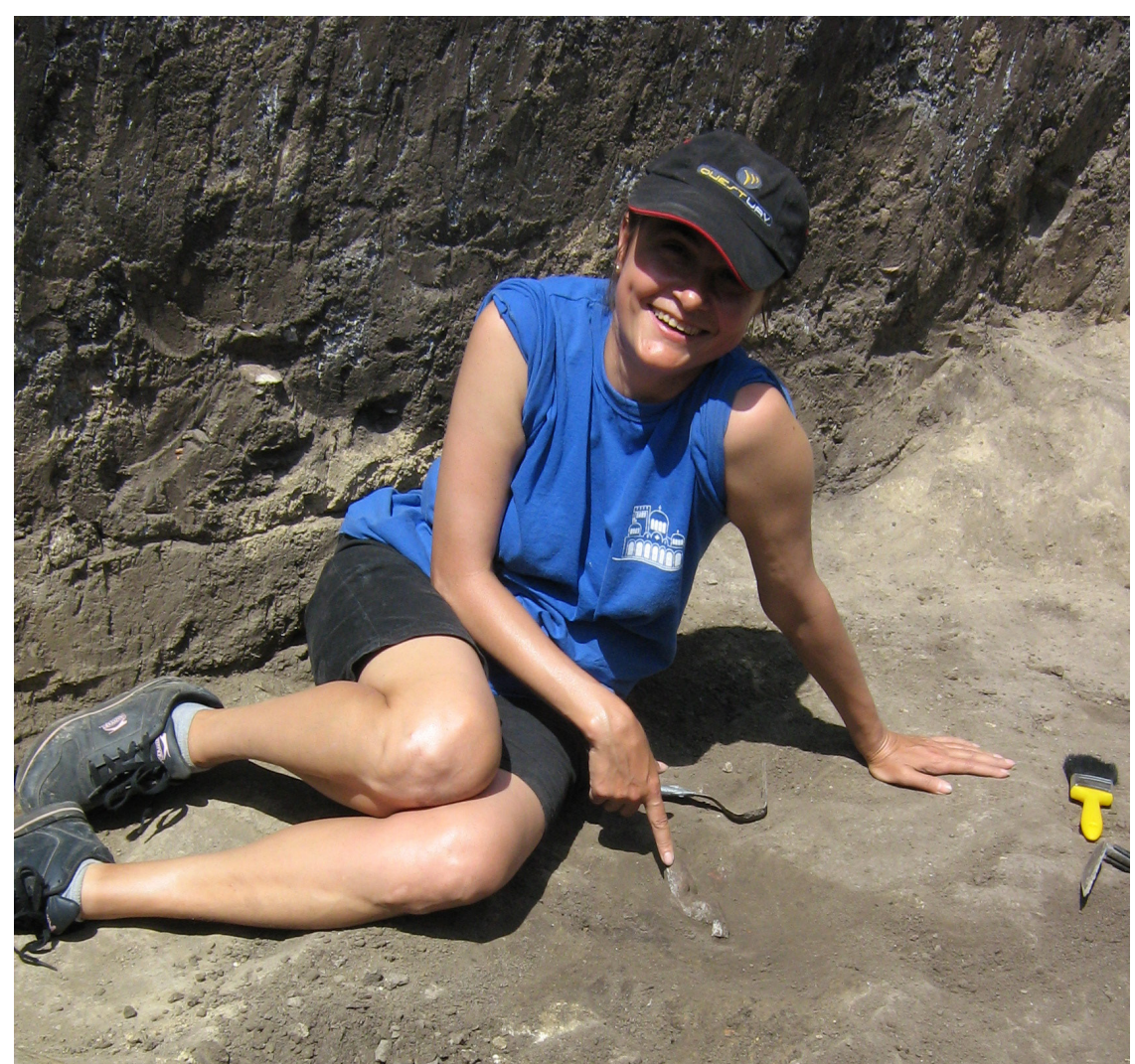

from the center, from the industrial hub of Shanghai, you ask where does it finish?

Tetiana Vodotyka - Nowhere?

John Chapman - You just can't say. And that's the characteristic, the principal characteristic of low-density urban form. They are huge $\ldots$ and diffuse.

Tetiana Vodotyka - So we can speak about two major ways high-density urbanism and low-density urbanism or it just seems to be this?

John Chapman - No, I think those are the two main points on a continuum. In between...

Tetiana Vodotyka - Is there something in between?

John Chapman - Yes. There is. Lots of really interesting sites. And that's quite hard to find. But I mean in modern terms people can define it more gradually. We are still trying to define low-density sites in prehistory. So we haven't quite got to the stage of the in-between sites. I think that's the next stage of the research agenda. At the current stage, we try to define low-density sites and we try to persuade people. I think we've got to persuade people generally the low-density model exists and it's following its implications. One of the implications is a different sort of model. And if you can actually push low-density urbanism back to the very beginning of urban development in Europe, that is really something!

Tetiana Vodotyka - Maybe you could tell about some more examples of low-density urbanism in prehistory societies except Tripillia. 
Plan of Nebelivka mega-site with proposed division into quarters (source: Archaeological Services Durham University and Y. Beadnell)

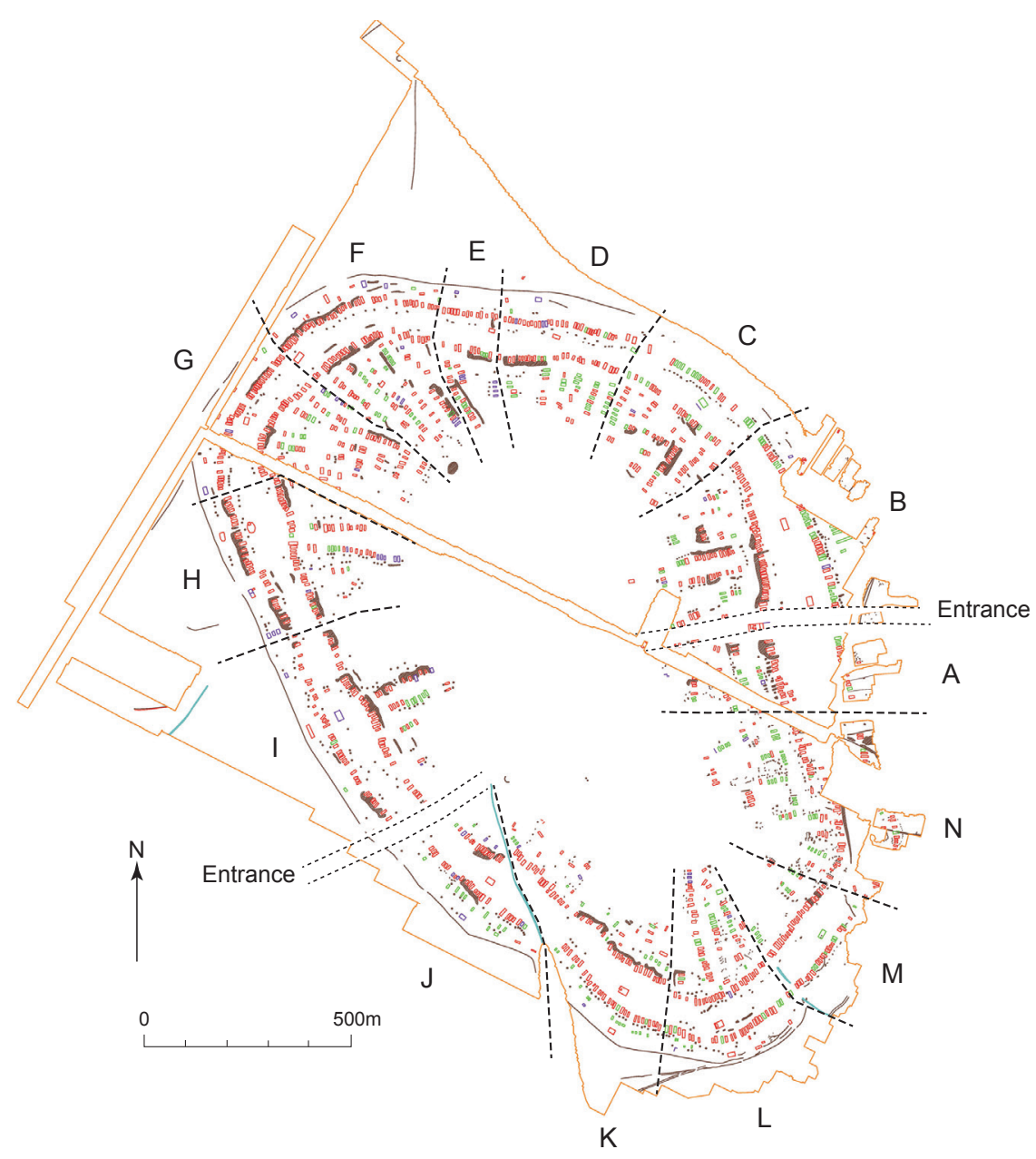

John Chapman - Yes, absolutely. If I think about the low-density agenda has made the Near Eastern archaeologists work in the Fertile Crescent with high-density sites, they made them think: oh, maybe we've got low-density settlements out there too! And they begin to find them. But not in the core area of the first cities which is the Fertile Crescent. There is another zone in the Northern area of the Tigris Euphrates which we call the Fragile Crescent which is the Northern periphery of the Fertile Crescent. They find low-density sites in the Fragile Crescent.

Bisserka Gaydarska - This is a very interesting thing because we heard about these sites only a couple months ago when we were at a conference in Canada. They were reported by somebody who works in the Near East. When we had this conversation we told him: now you are coming up with these sites because we have these big sites in Ukraine and we are trying to say: look, probably the earliest cities in the world have appeared in Ukraine and you try to question that, try to come up again with the first cities in your area. And he said: no, I have been telling people about these sites for a very long time. Fifteen years at least. But nobody among the Near Eastern archaeologists would pay attention because they are out of the ordinary, they are not what you expect, this is not what you look for.

Tetiana Vodotyka - They don't fit in the Gordon Childe model.

John Chapman - Yes.

Bisserka Gaydarska - These are very weird sites, and you don't consider them as very important evidence but now because there is 
this alternative agenda, there is this alternative thinking which suggests that this is could have a parallel phenomenon, not just the one, but the parallel... Things are shaking up and things people starting to realize that perhaps we should drop this evolutionary way which says this is the beginning and this is the end. But start to think about more like a tree, more like human evolution if you wish. Some species die and some survive and this is exactly the same. You can't possibly say that the social formation is something that should go from here to there in the same sort of way as we were told when we were growing up in communism from Band to tribe to state. No. Things are really more varied rather than strict. Unfortunately, some of these things do not survive, there is a branch that doesn't survive, and it doesn't get research attention because nobody is interested in dead ends, people are interested in successful cities, in successful places. Nobody is interested in something that didn't survive as Ukrainian sites. That's the big problem of the Ukrainian sites.

Tetiana Vodotyka - And that means that cities with low-density didn't exist for a long time.

Bisserka Gaydarska - That's exactly right. For prehistory, a hundred and fifty years is very short. For where we are now, a hundred and fifty is very long. But for prehistory hundred and fifty years is a very short time. You have to try to think in a different way. The low-density cities in the past had a very short duration.

Tetiana Vodotyka - What is the limit of duration? Ecology?

Bisserka Gaydarska - That's a very good question. Now you're opening a Pandora's box. It's a Pandora box because there are certain cases like in the case of Angkor Wat which is in Cambodia. Which certainly there was environmental reasons for that. And certainly, for some of the Maya sites in America, in Mesoamerica. There must be a high environmental component.

Well, when it comes to our sites it' hard to say why they fade away. I mean we don't have a lot of investigations and that's the other thing. People assume that it could be environmental but if you have no evidence and no research how do you prove that? And that's where John and myself have a bit of a fight with our German colleagues. We explained that we did some environmental studies to see what the impact of such sites would be on the environment and you would expect cities would have environmental impact that would be traceable in the way that we investigate this impact in the past. And maybe we find that there is a zero impact. We are still disagreeing ... perhaps we'll eventually agree. But basically, what it means that we can't possibly think that there were environmental reasons for the short duration so they thought that we have to look for other reasons why people have decided to move somewhere else. And in my view, this is where we probably disagree with Sasha Diachenko, is that this was a very sustainable form, people liked that way of aggregation. They liked it. And they maintained it. So this is not what something appears here and disappears. It appeared in various places in Ukraine. So as a whole that phenomenon lasted for almost seven hundred years. Only not in the same place. They were moving around. So that kind of human aggregation was very popular, and it was enduring. People liked it. 
Tetiana Vodotyka - Why do people like it?

Bisserka Gaydarska - Because it lasted for seven hundred years. We know that they have. We have sites which if you date this sites you know that the earliest starts whatever and the latest is whatever, so they sought that duration and put... this started there and this started there, therefore, we have seven hundred years of this settlement form being popular. There were not many sites. I'll just give you an example. If you have five thousand sites altogether for that period, these many sites are a very little percentage, they are only five percent. But so cities exist. So, you see, you know you have probably eighty percent villages, $15 \%$ towns and five percent cities. So, it very similar to Ukraine in the past. You have a massive number of villages or small sites, you have something in between and you have these very big sites which are not that many, there about five percent.

Tetiana Vodotyka - How much population could live there?

John Chapman - The answer really relates to this environmental study that we try to do. One view concerns the megasites. They are huge long term permanently occupied sites. This is the normal view. You might have fifteen or twenty thousand people in the sites in this view. But we've begun to challenge this normal model which suggests a much lower population and probably seasonal population with more people coming in certain seasons. Think of a rock festival, think of different sorts of social formations. And so we thinking of smaller seasonal cities, that's what we really thinking of at the moment. And there lots of seasonal cities in history, that's the interesting thing. I'll give you two examples. The one is the amazing Roman settlement in the Levant, with an occupation of one month in the year. It looks like it's there forever but many view it asa ceremonial center one month a year. And in the AD fourteenth century in Ethiopia, for instance, there were kings who went around from capital to capital. They moved around five or six times in the year. They spend two months in a certain place and then moved their capital. And they moved with thirty-five thousand people. They went round and round.

Tetiana Vodotyka - The moving city.

John Chapman - The moving city, exactly. That's just two examples, but there lots of these. So we are trying to come up with an alternative model, not Gordon Childe's so much as the alternative to the traditional Ukrainian view of the Tripillia megasites, they were very different places. We try to work out the implications. Of course, it has an implication from modern cities too. So many have large population seasonally like a rock festival. But not permanently, we don't believe that anymore.

Tetiana Vodotyka - I think that hardest question is what made people live that way? What made then choose low-density?

John Chapman - Well, the higher the density the higher the number of disputes. So bigger the number of problems you have with your neighbours, in a fact. So, high density means high dispute levels. And to resolve high disputes you need to have some kind of central authority, some kind of higher authority which have to solve problems with neighbors. And the converse of this in low-density is that you much more likely to have a space between yourself and your neighbours, so 
John Chapman in Nebvelivka village

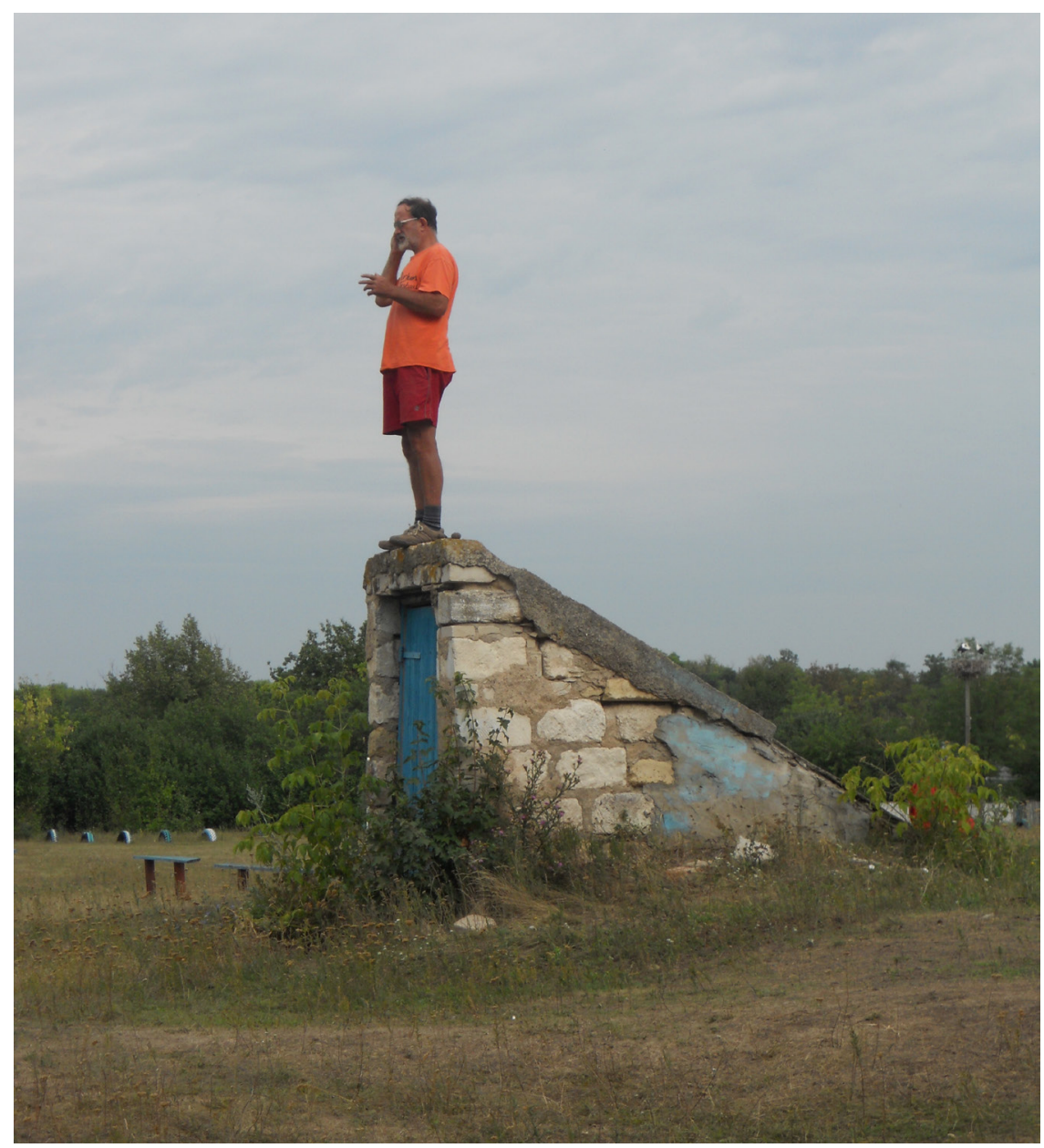

the disputes are not so great. And also on a site as big as Nebelivka, Nebelivka is two hundred and thirty-eight hectares, it's a really big site. If you have a problem in one area of Nebelivka with a horrible neighbour, you can move to another part of the megasite and you're still in the Nebelivka megasite. You just moved maybe five hundred meters or eight hundred meters away from this.

Tetiana Vodotyka - So, the reason seems similar to the modern one when people moved to the rural-urban area to combine work in the city and to live in kind of village and to combine advantages.

John Chapman - Yes, and the environment is much more socially productive and more pleasant and with much lower dispute ratios then you get in the city.

Tetiana Vodotyka - So, it means that human nature didn't change much from prehistoric times.

John Chapman - I think that this concerns particular solutions to problems. Some of the problems came up. Don't forget after Tripillia the density of settlements was much lower and size of sites was much smaller. Maybe for three thousand years. It was only when you have that big concentration that you have come up with new solutions. And this solution that you're talking about in modern times I think is the solution that Trypillian people found.

Tetiana Vodotyka - The thing is that Tripillian society didn't evolve to the city of high-density. For example, Rome did. 
High-density compact occupation at $\mathrm{Ur}$ (modified from Woolley \&amp; Mallowan 1976, pl. 124)

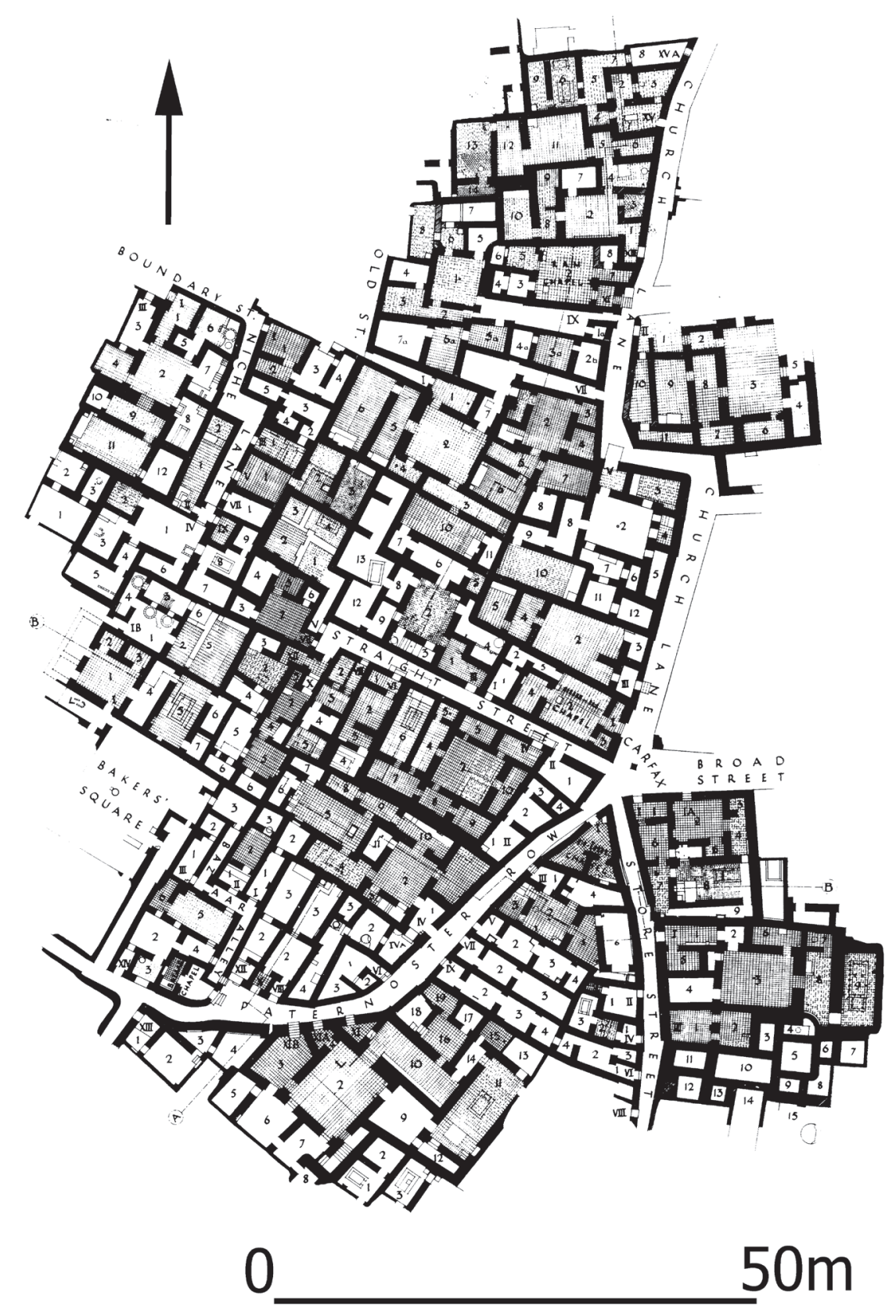

John Chapman - That is the very interesting point. The Trypillian people had two major characteristics that we are not sure about. We expected something different when we started our investigation. We expected it to be a more social differentiation with some elite, some hierarchy. But there is no sign of hierarchy on Tripillian sites. You've got community centers, big houses which are probably meeting houses. But that doesn't necessarily mean big bosses. Community houses built by the community to have meetings.

All of their things got together. When we excavated Nebelivka we expected special finds that showing high status. We found one gold hair ring in a whole site. No copper objects, we found no ritual finds. We couldn't believe it and we excavated the biggest assembly house on the site and there were no signs of the hierarchy at all, and that is really weird for Gordon Childe's theory. It doesn't work. And the other thing that is strange about Tripillian. Most cities have a hinterland, most high-density cities have a hinterland. But in low-density, the hin- 
terland idea is approached but the hinterland is part of the low-density city like a rural-urban. We looked around Nebelivka. We drew a circle five kilometres away from Nebelivka and walked to try to find settlements within five kilometres and couldn't found any. There was no hinterland. So, nothing going on.

Tetiana Vodotyka - Maybe my next question will be about modern urbanists. Would they agree with you?

Bisserka Gaydarska - Well, it's very difficult, I have to say. First of all, within archaeology, we have a small group of people, of like-minded people who are trying to make a strong case. We are really trying to put the evidence and to convince the world that there is this phenomenon that you cannot possibly ignore. If you are going with the classic view of urbanism you have to find an answer to this other evidence and try to explain what is going on, because it's not very good to say that all this is exceptional because so far what I hear is an answer: "Oh, this is an exception that proves the rule". This is not a valid thing, you have to say how because we are talking about people here. We are not talking about structure, it's real people who live in various ways. You have to be able to explain that. So there is no very strong answer to this apart from: "Oh, well this is an exception". As far as modern urban studies are concerned where we put the boundaries? Because as I said earlier to you how you compare the place where we live which is Durham which is smaller place then London and the same, how we go in the past. These are obviously very different phenomena and it's obviously very difficult to compare these things. Therefore, how do come up with one criteria that is valid for all times all across the world. And that's where I think that I have a contribution which, very immodestly, I have to suggest. If you look in absolute terms it would be very difficult. But if you go to old good Einstein and suggest that there's relativity and there's a relation that you have to look, then would be much easier to explain things. Because if you look for criteria... But if you look in terms of relations then it's much easier to explain some phenomenon. In Africa this site to this site they have particular relations with each other. These relations probably the same as the relations in Europe but the two forms are very different and what is important is that this site to this site this was the bigger site, more important site, this was the smaller site not so important but very much dependent on that. And this is what is important, this relationship is critical. But not to look at the sites as given as something that is fixed. You have to look in a different way. This is what I suggest is a different way. If you look in a different way that will help you to understand.

Tetiana Vodotyka - I've prepared a question about those people who plan modern cities. Is it possible to build a connection between prehistoric low-density sites and modern, maybe we should learn something from prehistoric times?

Bisserka Gaydarska - If you're an urban archaeologist this is a nightmare because if you want to excavate a site you know that you'll always find... there is a very long stratigraphy which says that people were living at the same time for a very long time, so they liked the place and they try to reorganize the place in which they want. And urban planners obviously give either this regards entirely what has hap- 
pened in the past and start from scratch and build their own city in a different way or try to develop around the city like Rome. Rome is the best example how people have respected the past and try to build a city around. But there are not many examples like that. So urban planners recently don't learn a lot from the past I have to say, they really... especially low-density sites because they are not... don't forget that people do not recognize these sites as important, so they hold them entirely undiscovered. It was again, in the last ten years in which people try to look at this evidence in different sort of way. We have a long way to go but Ukraine is really crucial to that, to surprise everybody. That's the other thing. I think that because people just think: "Ukraine? Where is that? Why there, why not here?". And people very surprised that it's not in Bulgaria or somewhere else because of the culture found in these sites has a very wide distribution. It goes into Romania, it goes into Ukraine, Moldova as well. These big sites appear only in Ukraine and Moldova, but not in Romania.

Tetiana Vodotyka - Why?

Bisserka Gaydarska - Exactly! Why?! And this is a very interesting question and people haven't answered that yet. I don't think there is a satisfactory answer what did that happen. That's the research agenda for the next generation to come. This is the sort of questions we have to ask rather than say: “Oh, no no no... It doesn't exist!". I think it's not positive to say: "It does not exist". Let's try to explain, let's try to see why it happened here not there, what are the factors. You're absolutely right. There are probably are environmental factors, but there are also social factors. People try to go very much with environmental factors rather than with the social. Think about what happens in Europe these days, which is this flush of the immigrants that coming. There's a war, they escape war and this is nothing to do with the environment. It's all to do with the political situation. It's political, it's economic. Sometimes, of course, it could be environmental. There is always more than one factor, that affects what happens and the exception of the particular place. Why density increases or decreases. You have to be really more flexible with the explanations that you have rather than fix the explanations.

John Chapman - In Romania there is very similar culture with similar kinds of beautiful painted pottery and figurines and all the stuff. Just before the first of megasites appeared these sites went through a phase of becoming smaller and more dispersed and forming essentially two-three-four-hectare villages, like. And if you start that you get used to living in two, three or four hectares villages. Like a lot of villages today all over the Balkans and Eastern Europe it is really difficult to reverse that and say: now we going to live in ten-hectare, now we are going to live in a twenty-, now we're going to live in a fifty-hectare village. If you are interested in this, these sites in this period in Romania could have started to come together and grow and nucleate.. Imagine European megasites in Romania, it didn't happen because it was just a different trajectory.

Tetiana Vodotyka - I've got a question. These megasites were huge, how did they manage with communication? What about moves, what about supplies, how to get from one site to another in case of danger, disaster? 
John Chapman - Well, yes. The megasite at Nebelivka is $1,8 \mathrm{ki}-$ lometres from one end to the other. The two other really big sites are Maidanetske and Talianki; they are even longer, with distances two kilometres from one end to the other. What you've got is the megasites, you've got little neighbourhoods, you've little groups of houses, and you've got groups of groups which we called Quarters. News would pass from quarter to quarter and within the quarter down to the neighborhood and all around. So, you don't have to have a social hierarchy to have an information hierarchy. People passing news from the one assembly house, one meeting house to the next. I mean, how far did we walk to the pub from the metro? A kilometer?

Tetiana Vodotyka - No, I think less. It was about fifteen minutes, ten minutes maybe.

John Chapman - If you had picked another pub that was two kilometres away then it should take thirty minutes, forty or thirty minutes of walking across the whole time. Sometimes, but also it depends on where the house is, so it might be longer because it was more social to visit your family. A colleague called Brian Buchanan has a program and he's running it now. We don't know the results but he's going to work out the most common routes around the megasite. It will be really interesting to see. It's almost sort of random walk. Almost, but a bit more structured, not much. We'll be seeing how people tended to walk around the megasite.

Tetiana Vodotyka - Okay. I think we should finish. Maybe a couple of words to sum up?

John Chapman - It's a challenge to define urbanism and show examples of it and then explain it. We're at the stage when we think that we can identify it. We can't necessarily explain it particularly well, but we're in the middle of that stage. That's where the research is at the moment and since the first meeting at a conference four years ago where we had heard about low-density sites at three continents we now know them in five continents. The more people can hear about it and think about it through your journal. The more interest there will be in this idea.

Bisserka Gaydarska - Well, to sum up, maybe we didn't mention Roland Fletcher. We have to give credit to him if it wasn't for him, for his long-life work actually to introduce this. And yet he came up with the idea not because he worked in Angkor Wat which is the primary center of low-density urbanism. But because one of his major works was the work called "The limits of settlement growth". He was trying to establish any patterns of human occupation. How do we start from hunter-gatherers, from the Palaeolithic to where we are now? Can we actually see some kind of ways in which humans behave in a similar way? And there are, there are always ways and he introduce several indexes according to which we can classify the way we live. This is not to do with anything but an evolutionary way of development, he's not saying: "oh, these are simple and these are complicated". No. It was more about these are the civilized people and these are not the civilized. It more to do: "why are people choosing to do that way, what happens?" And it's nice to see that some of the places go one way, they come back, so it's not so simple, it's not: "we all go that way". I think we have to acknowledge Roland Fletcher's work. 
We look at the evidence and we try to see it in a particular sort of way. There is no right or wrong way. What is bad is to deny something and say it doesn't exist. That's bad, that's really bad. Not to acknowledge new ideas. You have things to explain, as I was telling earlier. People try to undermine the evidence just because they can't explain it. We can't explain it, oh, let's forget about it! No. That's not how to do it. With the model that you have, you have to be able to explain these exceptions. If your model doesn't explain exceptions, you have to try again. You have to rework your model to acknowledge what is happening here and then you can expect that. But till that moment comes I'll stick to my low-density urbanism.

Tetiana Vodotyka - Thank you very much to you both.

Bisserka Gaydarska - It was a pleasure! 